\title{
Analisis Reaksi Pelaku UMKM Tahap Start Up Dalam Membandingkan Modal Kerja dan Pendapatan Usaha Sebelum dan Sesudah Adanya Inovasi Produk MAMIN di Wilayah Kediri dan Tulungagung
}

\author{
${\text { Udik Jatmiko', } \text { Srikalimah }^{2} \text {, Nurali Agus Najibul Zamzam³ }}^{3}$ \\ ${ }^{1}$ Dosen Prodi Manajemen Universitas Islam Kadiri Kediri \\ ${ }^{2}$ Dosen Prodi Akuntansi Universitas Islam Kadiri Kediri \\ ${ }^{3}$ Dosen Prodi Manajemen Universitas Islam Kadiri Kediri \\ *email : Jatmikoudik@gmail.com
}

ABSTRAK
Dalam penelitian ini ruang lingkup permasalahan yang akan dijadikan fokus penelitian adalah keinginan untuk mengkaji perbandingan modal usaha yang dikeluarkan dan pendapatan usaha yang diperoleh para pelaku UMKM Makanan dan minuman pada tahap start up di Wilayah Kediri dan Tulungagung dalam melakukan pengelolaan aktivitas-aktivitas strategi bisnisnya sebelum dan sesudah adanya kebijakan berinovasi.

Jumlah populasi dalam penelitian ini sebnyak 115 pelaku usaha, dan yang dijadikan sampel dalam penelitian ini sebanyak 89 responden. Teknik analisis Data menggunakan uji komparatif dengan pendekatan Uji Beda Paired Sample $t$ test.

Hasil penelitian menunjukkan bahwa modal usaha sesudah inovasi berbeda secara signifikan dengan modal usaha sebelum berlakunya inovasi produk. Hal ini dibuktikan dengan nilai probabilitas signifikan paired sample test dibawah 0,05. Perbedaan nilai rata-rata (mean) sebesar 3,764. Pendapatan usaha sesudah inovasi berbeda secara signifikan dengan pendapatan usaha sebelum berlakunya inovasi produk. Hal ini dibuktikan dengan nilai probabilitas signifikan paired sample test dibawah 0,05. Perbedaan nilai rata-rata (mean) sebesar 4,124.

Kata Kunci : Modal Usaha, Pendapatan Usaha, Inovasi Produk, Uji Beda Paired Sample t test. PENDAHULUAN

\section{Latar Belakang Masalah}

Keberadaan Usaha Kecil dan Menengah (UKM) di wilayah Indonesia khususnya di Jawa Timur merupakan pangsa pasar yang perlu mendapat suatu perhatian dan perhitungan saat ini. Suatu usaha yang dirintis dan dimulai dari level bawah dan terendah ini, ternyata berperan besar dalam upaya pengembangan dan peningkatan perekonomian di Indonesia. Usaha Mikro Kecil dan Menengah (UKM) telah memberikan sumbangsih dalam proses pengembangan suatu daerah, khususnya mengenai kemiskinan, hal ini disebabkan keberadaan usaha kecil dan menengah saat ini mampu memberikan warna tersendiri bagi masyarakat dalam membuka peluang bisnis.

Pada UU No 20 Tahun 2008 tentang UKM diantaranya pada bab IV pasal 6 memuat tahap-tahap yang akan dijalani adalah strat up, growth, expansion, dan going overseas. 
Khusus dalam penelitian ini nantinya yang akan menjadi pokok pembahasan mengenai UMKM yang berada pada tahap start up, hal ini dapat diartikan bahwa tahap start up merupakan jenis UMKM yang baru memulai kegiatan usahanya dalam kurun waktu kuran dari 7 tahun berjalan. Pada tahap awal ini banyak hal yang harus diperhatikan dan perlu dikembangkan khususnya mengenai faktor modal usaha serta pendapatan usaha tersebut atas keterkaitannya dengan inovasi produk yang dilakukan oleh para pelaku UMKM tahap strat up.

Sebuah usaha kecil dan menengah yang baru tumbuh, pada awalnya pasti merasakan kesulitan untuk sukses. Memerlukan waktu yang lama untuk mengembangkan usaha dalam mencapai titik keberhasilan. Namun, Ada tertentu mengapa bisnis atau usaha pada masa start up dapat berjalan lancar dan sukses, hal ini dikarenakan banyaknya unit usaha yang mempunyai tekat kuat untuk bertahan dalam proses pencapaian menuju kesuksesan. Hal itu juga tercermin pada beberapa UMKM makanan dan minuman pada tahap start up yang sukses, yang mampu bekerja secara efisien dalam mengelola keuangan dan mampu menjaga kestabilan kinerja keuangannya baik dari sisi modal ataupun pendapatannya.

Para pelaku UMKM makanan dan minuman pada tahap start up di Wilayah Kediri dan Tulungagung dalam menjalankan aktivitas usahnya juga sering melakukan beberapa inovasi tentang produk yang akan ditawarkan kepada konsumennya, para pelaku usaha tersebut sudah pasti memiliki sasaran atau segmen pasar sesuai dengan kapasitas produk makanan atau minuman yang coba akan dipasarkan. Namun, pada kenyataannya para pelaku usaha di bidang makanan dan minuman ini cenderung memiliki persepsi bahwa modal yang dikeluarkan harus selalu menghasilkan keuntungan tanpa memikirkan dan mempertimbangkan analisis financial apa yang akan dilakukan apabila para pelaku UMKM tersebut mengambil kebijakan seperti berinovasi. Keadaan riil yang dirasa saat ini adalah ketika berinovasi atas sebuah produk, karena di dasarkan pada keinginan para pelaku usaha atas keuntungan yang sebanyak-banyaknya, dan inovasi yang dilakukan juga ditengarahi oleh tingkat kebutuhan dan sikap konsumerisme konsumen.

Perkembangan usaha mikro antar kecamatan di wilayah kabupaten Kediri di dominasi oleh Usaha Kecil Menengah (UKM) sektor kuliner yaitu sebanyak 2843 pelaku usaha yang tersebar di 26 wilayah kecamatan. Usaha Kecil Menengah (UKM) sektor kuliner merupakan salah satu jenis usaha yang dapat mewakili dan cukup prospektif dalam perkembangan wilayah Kabupaten Kediri saat ini, hal ini ditunjukkan dengan semakin banyaknya usaha kuliner yang berkembang. Saat ini telah banyak muncul pengusaha makanan dan produk makanan hasil olahan lokal baik makanan khas daerah maupun makanan konsumsi harian, hal ini dapat disebabkan karena semakin besarnya permintaan serta semakin meningkatnya kebutuhan masyarakat. Kondisi ini menyebabkan usaha ini semakin menjanjikan diminati para wirausaha. Disamping cukup prospektif, UKM makanan juga dihadapi sejumlah tantangan berupa munculnya makanan impor, makanan susbtitusi dan makanan produk olahan dari daerah lain dengan kemasan dan rasa yang bervariatif yang nantinya mengindikasikan penurunan terhadap kinerja para pelaku usaha. Sedangkan khusus untuk para pelaku start up di sektor makanan dan minuman sebanyak 254 pelaku usaha. Sedangkan di Kota kediri Jumlah Usaha Mikro, Kecil, dan Menengah (UMKM) di Kota Kediri, Jawa Timur, semakin meningkat setiap tahunnya, di mana pada 2017 terdata sekitar 26.000 usaha dan kemudian naik menjadi sekitar 31.000 usaha pada 2018. Data perkembangan UMKM juga ditunjukkan Badan Pusat Statistik Tulungagung yang menyatakan bahwa pertumbuhan UMKM di Tulungagung dari tahun 2016-2017 mengalami fluktuasi, jumlah pertumbuhan UMKM terbesar pada tahun 2016 sebesar 48.650 atau 4,017\% dan jumlah pertumbuhan UMKM pada tahun 2017 sebesar 51.569 atau 0,502\% artinya jumlah UMKM terus mengalami peningkatan. 
Problematika saat ini khususnya para pelaku start up di sektor makanan dan minuman adalah masih kurang maksimalnya terobosan akan produknya atau biasa kita sebut dengan inovasi, kebanyakan para pelaku usaha awal ini masih terkendala masalah perisinian PIRT (Pangan Industri Rumah Tangga), selain itu juga masih berfokus pada titik penguatan produk-produknya dipasaran melalui beberapa even yang dilaksnakan pemerintah, instansi atau non kepemerintahan. Efek yang terjadi adalah kurangnya perhatian pada internalisasi inovasi produk-produknya, yang lebih mengkhawatirkan lagi jika dibandingkan dengan kebijakan adanya MEA saat ini, para pelaku usaha juga merasa butuh dorongan dari berbagai pihak baik dari segi materiil atau non materiil untuk tetap bertahan dengan produknya.

Dalam penelitian ini, yang dilakukan adalah adanya keinginan untuk mengkaji perbandingan modal usaha yang dikeluarkan dan pendapatan usaha yang diperoleh para pelaku UMKM pada tahap start up di Wilayah Kediri dan Tulungagung dalam melakukan pengelolaan aktivitas-aktivitas strategi bisnisnya sebelum dan sesudah adanya kebijakan berinovasi. Kemudian bagaimana reaksi dan pandangan para pelaku usaha tersebut dalam konsep perbandingan modal dan pendapatan yang dikembangkan dengan inovasi produk. Dengan melakukan analisis statistik parametrik menggunakan uji Pairred sample $t$ test diharapkan akan didapatkan hasil perbandingan mengenai modal dan pendapatan usaha dalam menentukan kebijakan inovasi sebuah produk, hal ini dirasakan akan memberi reaksi kepada para pelaku usaha dalam menentukan kelanjutan usaha yang unggul dan kompetitif sehingga diharapkan akan dapat menjelaskan di mana posisi tanggung jawab financial dapat ditingkatkan karena pengelolaan modal dan pendapatan usaha yang efektif dan berkesinambungan memungkinkan para pelaku UMKM pada tahap start up di Wilayah Kediri dan Tulungagung untuk memiliki keunggulan kompetitif sehingga mampu bersaing di pasar global.

\section{Identifikasi Masalah}

Berdasarkan masalah yang telah dijelaskan di atas, maka penelitian ini akan menggambarkan identifikasi suatu masalah dari latar belakang penyusunan penelitian ini bahwa modal dan pendapatan usaha yang tidak menentu dirasakan para pelaku UMKM pada tahap start up saat ini mendorong pemikiran peneliti untuk mengembangkan konsep ilmiah dengan tingkat inovasi yang telah dilakukan agar memiliki keunggulan dan mampu mengambil kebijakan strategi bisnis, dapat dianalisis berdasarkan atas beberapa faktor:

1. Tingkat kemampuan modal yang dikeluarkan dalam menghasilkan laba.

2. Penjualan yang tinggi tidak memberikan banyak pengaruh terhadap peningkatan pendapatan.

3. Semakin rendah tingkat inovasi produk para pelaku UMKM makanan dan minuman pada tahap start up.

\section{Rumusan Masalah}

Berdasarkan latar belakang yang diuraikan sebelumnya, maka rumusan masalah sebagai berikut :

1. Apakah ada perbedaan antara modal yang dikeluarkan sebelum dan sesudah melakukan inovasi produk oleh para pelaku UMKM makanan dan minuman pada tahap start up di wilayah Kediri dan Tulungagung.

2. Apakah ada perbedaan antara pendapatan yang diterima sebelum dan sesudah melakukan inovasi produk oleh para pelaku UMKM makanan dan minuman pada tahap start up di wilayah Kediri dan Tulungagung. 


\section{Tujuan Penelitian}

Tujuan dari penelitian yang akan dilakukan sebagai berikut :

1 Untuk menganalisis perbedaan antara modal yang dikeluarkan sebelum dan sesudah melakukan inovasi produk oleh para pelaku UMKM makanan dan minuman pada tahap start up di wilayah Kediri dan Tulungagung.

2 Untuk menganalisis perbedaan antara pendapatan yang diterima sebelum dan sesudah melakukan inovasi produk oleh para pelaku UMKM makanan dan minuman pada tahap start up di wilayah Kediri dan Tulungagung.

\section{LANDASAN TEORI}

\section{MODAL}

Dalam bukunya Kasmir (2006:90), Untuk mendirikan atau menjalankan suatu usaha diprlukan sejumlah modal (uang) dan tenaga (keahlian). Modal dalam bentuk uang diperlukan untuk membiayai segala keperluan usaha, mulai dari biaya prainvestasi, pengurusan izinizin, biaya inestasi untuk pembelian aktiva tetap, sampai dengan modal kerja. Disamping itu, modal juga diperlukan untuk memibayai operasi usaha pada saat bisnis tersebut dijalankan. Sementara modal keahlian diperlukan untuk mengelola atau menjalankan usaha tersebut.

Dalam bukunya Purwaji (2016:24) Modal atau ekuitas adalah hak residual atas aset entitas (perusahaan) setelah dikurangi dengan semua kewajibannya (SAK ETAP 2009, 2.12c. elemen-elemen yang ada di dalam ekuitas tergantung dari bentuk perusahaan. Menurut wikipedia modal merupakan dasar yang wajib dimiliki dalam menjalankan usaha, jika hendak mengambil keuntungan dari usaha yang dilakukan baik secara individual maupun badan organisasi.

\section{PENDAPATAN}

Sukirno (2001) dalam penelitian Sri Endang (2015) menyatakan bahwa pendapatan pada dasarnya merupakan balas jasa yang diterima pemilik faktor produksi atas pengorbannya dalam proses produksi. Masing-masing factor produksi seperti : tanah akan memperoleh balas jasa dalam bentuk sewa tanah, tenaga kerja akan memperoleh balas jasa berupa upah atau gaji, modal akan memperoleh balas jasa dalam bentuk bunga modal, serta keahlian termasuk para enterprenuer akan memperoleh balas jasa dalam bentuk laba.

Dalam pengertian umum pendapatan adalah hasil pencaharian usaha. Budiono (2002) mengemukakan bahwa pendapatan adalah hasil dari penjualan faktor-faktor produksi yang dimilikinya kepada sector produksi. Menurut (Nordhaus, 2000) pendapatan merupakan nilai dari seluruh barang dan jasa yang dihasilkan oleh suatu badan usaha dalam suatu periode tertentu. Selanjutnya, pendapatan juga dapat di definisikan sebagai jumlah seluruh uang yang diterima oleh seseorang atau rumah tangga selama jangka waktu tertentu (biasanya satu tahun), pendapatan terdiri dari upah, atau penerimaan tenaga kerja, pendapatan dari kekayaan seperti sewa, bunga dan deviden, serta pembayaran transfer atau penerimaan dari pemerintah seperti tujangan sosial atau asuransi pengangguran. 


\section{METODOLOGI PENELITIAN}

\section{Populasi dan Sampel}

Populasi yang menjadi sasaran dalam penelitian ini adalah usaha kecil menengah dalam bidang makanan dan minuman di wilayah Kediri dan Tulungagung, yang terdaftar pada Dinas Koperasi Dan Usaha Kecil Menengah Kediri dan Tulungagung yang telah melakukan kebijakan inovasi. Adapun jumlah populasi pelaku UMKM pada tahap start up tersebut sebanyak 115 UMKM. Pengambilan sampel dilakukan dengan teknik purposive sampling" (Sugiyono, 2016), Pengertian Purposive Sampling adalah teknik penentuan sampel dengan cara mengambil subyek bukan didasarkan atas strata, random, atau daerah, tetapi didasarkan pada tujuan tertentu, orang tersebut dapat digunakan sebagai sampel (responden) selama dipandang layak menjadi sumber data.Jumlah responden dalam penelitian ini yang menjadi objek penelitian sebanyak 89 pelaku usaha.

\section{Analisa Data Penelitian}

Adapun tehnik analisis yang akan dilakukan penulis dalam melakukan penelitian ini diantaranya sebagai berikut :

1. Uji Paired Sample test

Teknik statistik yang berfungsi untuk menguji signifikansi perbedaan Mean antara dua kelompok atau variabel yang berskala interval/ratio dan berdistribusi normal.

$$
t=\frac{\bar{x}_{1}-\bar{x}_{2}}{\sqrt{\frac{s_{1}^{2}}{n_{1}}+\frac{s_{2}{ }^{2}}{n_{2}}}-2 r\left(\frac{s_{1}}{\sqrt{n_{1}}}\right)\left(\frac{s_{2}}{\sqrt{n_{2}}}\right)}
$$

Keterangan :

$\bar{x}_{1}$ : rata-rata sampel 1

$\bar{x}_{2}$ : rata-rata sampel 2

$\mathrm{S}_{1} \quad$ : simpangan baku 1

$\mathrm{S}_{2}$ : simpangan baku 2

$\mathrm{S}_{1}^{2}$ : varian sampel 1

$\mathrm{S}_{2}{ }^{2}$ : varian sampel 1

$\mathrm{r} \quad$ : korelasi antar variabel

\section{Uji Hipotesis}

Pengujian hipotesis ini menggunakan uji beda dua rata-rata dari dua kelompok observasi berpasangan ( $t$-test: Paired Sample test) dengan derajat signifikansi 5\% (Sugiyono, 2016). Dalam pengujian ini menggunakan hipotesis:

1. Hipotesis pertama

Ho: $\mu$ setelah inovasi $=\mu$ sebelum inovasi

Modal usaha sesudah inovasi tidak berbeda secara signifikan dengan Modal usaha sebelum berlakunya inovasi produk.

Ha: $\mu$ setelah inovasi $\neq \mu$ sebelum inovasi

Modal usaha sesudah inovasi berbeda secara signifikan dengan Modal usaha sebelum tanggal berlakunya inovasi produk.

2. Hipotesis kedua

Ho: $\mu$ setelah inovasi $=\mu$ sebelum inovasi 
tidak ada perbedaan pendapatan usaha secara signifikan sebelum dan sesudah berlakunya inovasi produk.

Ha: $\mu$ setelah inovasi $\neq \mu$ sebelum inovasi

ada perbedaan pendapatan usaha secara signifikan sebelum dan sesudah berlakunya inovasi produk.

\section{HASIL PENELITIAN DAN PEMBAHASAN}

\section{Hasil Uji Paired Sample Test Variabel Modal Usaha}

Hasil perhitungan menunjukkan bahwa rata-rata (mean) modal usaha sebelum dilakukannya inovasi produk sebesar 34,08 dengan standar deviasi 2,873. Sedangkan rata-rata modal usaha sesudah diadakan inovasi produk sebesar 30,31 dengan standart deviasi sebesar 3,253.

Hasil perhitungan dapat dijelaskan bahwa hubungan kedua variabel dinyatakan sebesar 0,226 dengan nilai signifikasi 0,033. Dapat diartikan bahwa hubungan antara kedua variabel antara modal usaha sebelum inovasi dan modal usaha sesudah inovasi berhubungan secara nyata dalam kategori lemah, hal ini juga dibuktikan dengan nilai Signifikasinya $<0,05$.

Untuk menilai hipotesis dalam penelitian ini menggunakan pedoman bahwa :

a Jika probabilitas (Sig.) < 0,05 maka Ho ditolak dan Ha diterima artinya Modal usaha sesudah inovasi berbeda secara signifikan dengan Modal usaha sebelum berlakunya inovasi produk.

b Jika probabilitas (sig.) $>0,05$ maka Ho diterima dan Ha ditolak artinya Modal usaha sesudah inovasi tidak berbeda secara signifikan dengan Modal usaha sebelum berlakunya inovasi produk.

Berdasarkan perhitungan di atas, maka dapat dijelaskan hasil analisis sebagai berikut :

1. Terlihat bahwa nilai t hitung sebesar 9,289 dengan nilai probabilitas 0,000 lebih kecil dari ketentuan 0,05. maka dapat disimpulkan bahwa Ho ditolak dan Ha diterima yang berarti modal usaha sesudah inovasi berbeda secara signifikan dengan modal usaha sebelum berlakunya inovasi produk.

2. Hasil perhitungan tersebut juga menyatakan bahwa terjadi perbedaan nilai rata-rata (mean) sebesar 3,764 hal ini berarti selisih rata-rata modal usaha sebelum inovasi dengan modal usaha sesudah inovasi.

\section{Hasil Uji Paired Sample Variabel Pendapatan Usaha}

Hasil perhitungan menunjukkan bahwa rata-rata (mean) pendapatan usaha sebelum dilakukannya inovasi produk sebesar 24,27 dengan standar deviasi 2,601. Sedangkan rata-rata pendapatan usaha sesudah diadakan inovasi produk sebesar 28,39 dengan standart deviasi sebesar 5,551.

Hasil perhitungan dapat dijelaskan bahwa hubungan kedua variabel dinyatakan sebesar 0,362 dengan nilai signifikasi 0,000. Dapat diartikan bahwa hubungan antara kedua variabel antara pendapatan usaha sebelum inovasi dan pendapatan usaha sesudah inovasi berhubungan secara nyata dalam keadaan yang lemah, hal ini dibuktikan dengan nilai Signifikasinya $0,000<0,05$

Berdasarkan perhitungan, maka dapat dijelaskan hasil analisis sebagai berikut :

1. Terlihat bahwa nilai $t$ hitung sebesar 7,468 dengan nilai probabilitas 0,000 lebih kecil dari ketentuan 0,05. maka dapat disimpulkan bahwa Ho ditolak dan Ha diterima yang 
berarti pendapatan usaha sesudah inovasi berbeda secara signifikan dengan pendapatan usaha sebelum berlakunya inovasi produk.

2. Hasil perhitungan tersebut juga menyatakan bahwa terjadi perbedaan nilai rata-rata (mean) sebesar 4,124 hal ini berarti selisih rata-rata pendapatan usaha sebelum inovasi dengan pendapatan usaha sesudah inovasi.

\section{Perbedaan Modal Usaha Sebelum dan Sesudah Inovasi Produk}

Berdasarkan hasil penelitian diperoleh hasil bahwa modal usaha sesudah inovasi berbeda secara signifikan dengan modal usaha sebelum berlakunya inovasi produk. Hal ini dibuktikan dengan nilai perhitungan statistik t hitung sebesar 9,289 dengan nilai probabilitas 0,000 lebih kecil dari ketentuan 0,05.

Temuan tersebut mengindikasikan bahwa para pelaku usaha UKM tahap start up di wilayah Kediri dan Tulungagung rata-rata memiliki persepsi bahwa modal yang dikeluarkan dalam menghasilkan produk secara operasional berbeda saat sebelum inovasi. besarnya modal usaha sebelum inovasi ini dadasari karena kegiatan produksi dan operasional yang begitu besar daläm memperkenalkan produk-produknya, tidak jarang bahkan para pelaku usaha juga mengalami kesulitan modal dalam menjalankan roda kegiatan usahanya. Dalam fase ini reaksi pelaku usaha tahap start up di sektor makanan dan minuman berfikir bahwa perlu adanya kreativitas berfikir dalam menjalankan aktivitas usahanya agar tetap bertahan dan berkembang dalam menghadapi beberapa persaingan usaha. Reaksi berbeda juga ditunjukkan oleh para pelaku yang melakukan kebijakan inovasi terhadap produknya, perbedaan sikap ini muncul ketika para pelaku usaha mayoritas berfikir dalam melakukan inovasi kebutuhan modal usaha dirasa juga akan mengalami titik peningkatan. Dalam fase ini untuk tetap mengikuti perkembangan inovasi yang akan dilakukan biasanya didukung oleh sumber-sumber modal baik dari pinjaman maupun sumbangan dan dana hibah bantuan pemerintah. maka dari itu, perbedaan reaksi para pelaku usaha cenderung meningkat manakala usahanya tersebut terbilang menurun dan akan melakukan proses inovasi sebagai salah satu solusi agar terus berkembang.

\section{Perbedaan Pendapatan Usaha Sebelum dan Sesudah Inovasi Produk}

Berdasarkan hasil penelitian diperoleh hasil bahwa pendapatan usaha sesudah inovasi berbeda secara signifikan dengan pendapatan usaha sebelum berlakunya inovasi produk. Hal ini dibuktikan dengan nilai perhitungan statistik nilai t hitung sebesar 7,468 dengan nilai probabilitas 0,000 lebih kecil dari ketentuan 0,05 .

Hasil temuan tersebut dapat dijelaskan bahwa rata-rata reaksi para pelaku usaha sektor makanan dan minuman tahap start up di Wilayah Kediri dan Tulungagung mengalami fluktuasi pendapatan setelah melakukan kebijakan inovasi. Secara deskripsi dapat digambarkan pada saat inovasi itu dilakukan rata-rata pelaku usaha tersebut berjuang keras untuk memperkenalkan produk-produk hasil olahannya yang baru di revitalisasikan kembali. Banyak para pelaku usaha tersebut berpendapat bahwa besaran pendapatan yang diterima masing-masing mengalami perbedaan dengan pada saat sebelum melakukan inovasi produk, peningkatan pendapat usaha itu sendiri dapat terjadi ketika produk yang ditawarkan sudah dikenal oleh beberapa masyarakat umum diwilayah pasar produknya tersebut. Merujuk pada hasil penelitian tersebut mengindikasikan bahwa inovasi yang dilakukan oleh setiap individu para pelaku usaha dapat bereaksi efektif juga terhadap perkembangan pendapatan usaha dari akivitas operasional usaha yang dijalankan, tentunya dengan strategi-strategi pengembangan produk stelah dilakukannya inovasi 


\section{PENUTUP}

\section{Kesimpulan}

Berdasarkan analisis pembahasan yang telah dilakukan, dapat disimpulkan hasil penelitian sebagai berikut :

1. Modal usaha sesudah inovasi berbeda secara signifikan dengan modal usaha sebelum berlakunya inovasi produk. Hal ini dibuktikan dengan nilai probabilitas signifikan paired sample test dibawah 0,05 . Perbedaan nilai rata-rata (mean) sebesar 3,764.

2. Pendapatan usaha sesudah inovasi berbeda secara signifikan dengan pendapatan usaha sebelum berlakunya inovasi produk. Hal ini dibuktikan dengan nilai probabilitas signifikan paired sample test dibawah 0,05. Perbedaan nilai rata-rata (mean) sebesar 4,124 .

\section{Saran}

Berdasarkan kesimpulanyang telah diuraikan di atas, maka peneliti dapat memberikan saran sebagai berikut :

1. Pada faktor modal terjadi perbedaan yang signifikan antara sebelum dan sesudah melakukan inovasi, akan tetapi dengan adanya inovasi semakin menunjukkan penurunan modal. Hal ini harus menjadi perhatian lebih dari para pelaku usaha di Sektor makanan dan minuman wilayah Kediri dan Tulungagung untuk lebih baik lagi mengelola permodalan usahanya baik melalui modal sendiri atau modal pinjaman agar dapat menyeimbangkan kegiatan operasional usaha, sehingga saat melakukan inovasi tidak terbebani oleh keadaan kekurangan modal.

2. Terjadi perbedaan antara pendapatan sebelum dan sesudah melakukan inovasi produk, akan tetapi pendapatan sesudah inovasi mengalami peningkatan. Hal ini dapat mengindikasikan bahwa para pelaku usaha sebaiknya perlu melakukan inovasi dalam setiap proses pengembangan produk, karena pada saat inovasi tersebut dilakukan ada efek yang mengarah pada pendapatan usahanya.

\section{DAFTAR PUSTAKA}

Bungin, Burhan (2009). Metodologi penelitian Kuantitatif, Jakarta: Penerbit Kencana Prenada Media Grup.

Endang, Sri Rahayu. (2014). Studi Komparatif Perubahan Pendapatan Usaha Warung Tradisional Sebelum Dan Sesudah Adanya Warung Retail Modern Di Kecamatan Medan Timur. Jurnal Manajemen \& Bisnis Vol 14 NO. 02 Oktober 2014 ISSN 1693-7619. Diakses 2 Mei 2017.

Kasmir. (2012). Kewirausahaan. edisi revisi, cetakan ke-7. Jakarta : PT. Raja Grafindo.

Suryana. (2014). Kewirausahaan Kiat Dan Proses Menuju Sukses. Edisi 4. Jakarta : Penerbit Salemba Empat.

M. Reeve James, Carl S. Warren, Jonathan E.Duchac, Ersa Tri Wahyuni, Gatot Soepriyanto, Amir Abadi Jusuf dan Chaerul D. Djakman. (2009). Pengantar Akuntansi adaptasi Indonesia Buku 1. Jakarta : Penerbit Salemba Empat. 
Purwaji, Agus.,Wibowo dan H. Murtanto. (2016). Pengantar Akuntansi 1, Edisi 2, penerbit Salemba Empat.

Sugiyono. (2015). Analisis Penyediaan Dan Penggunaan Modal Kerja UMKM (Usaha Mikro, Kecil Dan Menengah) Dalam Meningkatkan Laba Usaha Pada KUB (Kelompok Usaha Bersama) ALAM LESTARI DEPOK. Prosiding Semiar Nasional Pendidikan Ekonomi \& Bisnis Fakultas Keguruan dan Ilmu Pendidikan Universitas Sebelas Maret Surakarta Sabtu, 07 November 2015. ISBN: 978-602-8580-19-9

Sugiyono. (2016). Metode Penelitian Kuantitatif kualitatif dan H \& D, Bandung : CV. Alfabeta.

Undang-Undang Republik Indonesia Nomor 20 Tahun 2008 Tentang Usaha Mikro Kecil Dan Menengah.

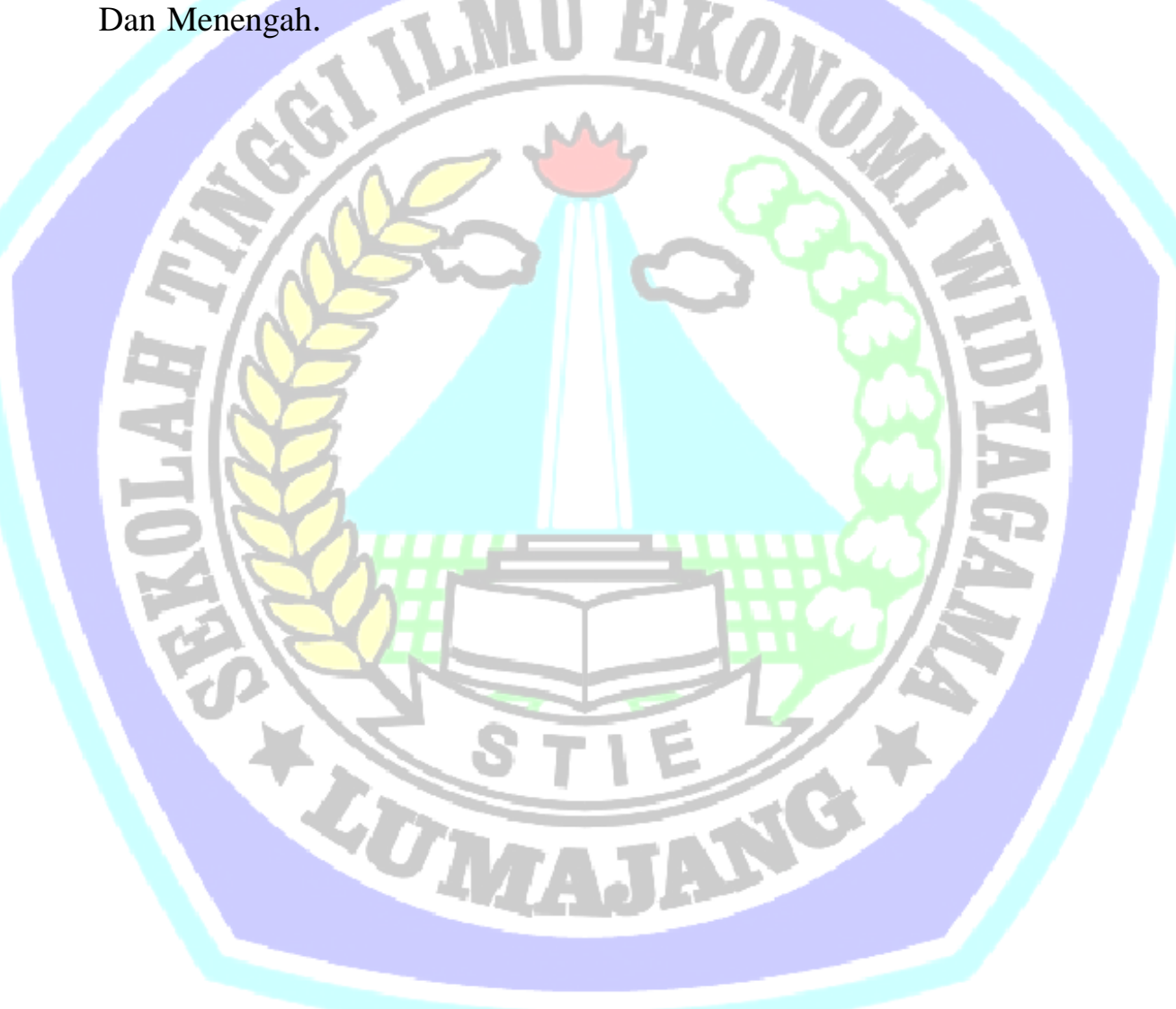

